\title{
AN ANALYSIS OF CHOSEN ASPECTS OF ENVIROMENT-RELATED CONDITIONS FOR BUILDING INVESTMENTS
}

\author{
Jolanta Harasymiuk ${ }^{1, *}$, Elżbieta Hanna Szafranko ${ }^{1}$ \\ 1 University of Warmia and Mazury in Olsztyn, Faculty of Geodesy, Geospatial and Civil Engineering, Institute \\ of Building Engineering, Heweliusza str. 4, 10-724 Olsztyn, Poland \\ * Corresponding author's e-mail: jolanta.harasymiuk@uwm.edu.pl
}

Received: 2017.05.24

Accepted: 2017.08.01 Published: 2017.09.01

\begin{abstract}
The construction of building projects will always result in a degree of interference in the local environment. Legal regulations intended for the most effective protection of natural resources involve a range of procedures, without which the imitation of building projects is not possible. It concerns all investments, but the regulations especially emphasize the ones, which may negatively affect the environment. A decision on environment-related conditions, which is foreseen in the process, requires the preparation of many specialist documents which constitute attachments to the application of its issuance. One of the problems related to this procedure is the time lag associated with an environmental decision, which is difficult to determine or predict. The periods of waiting for issuing a decision for building investments of a different character were analysed in the article. The reason for this situation was also analyzed.
\end{abstract}

Keywords: investment activities, environmental protection, environmental decision

\section{INTRODUCTION}

Environment-related conditions of carrying out building investments in Poland are one of the most important elements in the investment process. The time-frame for Poland joining the EU resulted in the necessity of harmonizing Polish regulations with the EU norms [CiechanowiczMcLean 2001]. The process of harmonization introduced new obligations connected with environmental protection while making a building investment. Environmental reports constitute an example of such legal requirements related to the protection of areas of special natural value [Ejdys et al. 2012]. Poland, like other European countries, has witnessed the continuous development of construction technology as well as new construction techniques, and because of the economic growth, there is a need to construct new projects. In this aspect, designers and constructors face enormous challenges. The aim of the article is to present the requirements related to the preparation of a building investment with respect to environmental protection, as well as to analyze the requirements related to obtaining an appropriate decision and to the examine the length of time for the entire procedure for various types of projects [Szafranko 2014].

\section{METHODS AND RANGE OF RESEARCH}

In the article the decisions for environmentrelated conditions were taken into account, which were issued in the years of 2012-2015 by the regional director of environmental protection, hence of quite a high degree of importance. For the purpose of the article, the environmental decisions requiring the preparation of an environmental report were selected, as well as the ones requiring the preparation of a detailed assessment of environmental impact (on the basis of the qualification in the Decree on the investments capable of exerting a significant impact on the environment from 2004 or 2010 and as a result of a discretionary procedure and the decision issued without 
making an assessment of the environmental impact and without an environmental report).

The analysis was based on the information obtained in a query of the documentation collected in the seat of the Regional Direction of Environment Protection in Olsztyn. The information obtained was analyzed statistically and the results were presented in the form of three linear graphs showing the trends concerning the changes of values in the categories researched.

\section{THE FORMAL-LEGAL BASES OF THE ENVIRONMENT PROTECTION IN THE PROCESS OF BUILDING INVESTMENT}

In November 1999, a parliamentary act reforming the ministry of Environment Protection, Natural Resources and Forestry came into force, which among other things changed its name to the Ministry of Environment. At the same time, the act shifted part of duties from the national institutions to the services and bodies of regional and local governments (the Marshals of Provinces, Heads of Districts, Mayors of Cities, towns and the Heads of rural Municipalities). This law resulted in a new division of competences and an increase in the numbers of institutions responsible for the implementation of the regulations. In 2004, the so-called competence parliamentary act was passed, shifting a considerable part of duties of the Civil Service to the regional and local bodies. The consecutive years up till 2009 brought the granting the majority of competency over to the Marshals of the Provinces. The supervision of the law was now in the hands of a head of province. In the years 2008-2009, further parliamentary acts were passed, limiting the competency of a head of province in the field of environmental protection and creating the Regional Directions of Environment Protection, as well as shifting a part of competence in the field of making legal forms of environmental protection at the provincial level (i.e. the Provincial Parliament) and at the level of the municipal government (Municipal Councils, Towns Councils) [Wierzbowski, Rakoczy 2007].

The state administrative bodies in the field of environmental protection at the national level include the Council of Ministers, the Environment Minister with the Chief Conservator of Nature, the General Director of Environmental Protection, and the Directors of National Parks. Among the advisory bodies one can enumerate: the State
Council of Nature Protection, the State Council of Environmental Protection, and the Scientific Council of the National Park (acting alongside the Director of National Parks).

The governmental bodies and the administration at the Provincial level comprise: Voivode, a Regional Director of Environment Protection, the Provincial Parliament. On the other hand, the advisory bodies are: a regional Council of Environmental protection, a Provincial Board for the Assessment of the Impact on the Environment, Thematic boards (e.g. of environmental protection) acting alongside the Provincial Parliament and the Council of the Park of the Protected Landscape or a committee of the Assemble of Landscape Parks.

The governmental and administrative bodies at the local level are include the Head of the District, the Mayors of cities and towns, heads of municipalities with the Town Conservator of Nature.

\section{KINDS OF UNDERTAKINGS THAT SHALL BE MADE SUBJECT TO THE PROCEDURE OF ENVIRONMENTAL IMPACT ASSESSMENT}

According to the parliamentary act of October 3, 2008 on access to information about the environment and environmental protection, the contribution of the community in environmental protection and about the assessment of potential environmental impact [Journal of Law 2008 No 199] an environmental decision is required for all the undertakings, which:

a) may always influence the environment considerably, in the areas are covered by Natura 2000,

b) may potentially have a significant influence the environment, in the areas covered by Natura 2000.

While applying for a decision of environmentrelated conditions for carrying out a project, the investor submits a motion for issuing a decision and includes two basic attachments: an information card for the undertaking and/or a report of the assessment of environmental impact.

As far as investments are concerned, decisions are made on the basis of only an information card of the undertaking.

An investment may be qualified to one of the above-mentioned categories which require preparation of expert environmental appraisal in the 
form of a report as per the Decree of the Council of Ministers of November 9, 2010 on projects which may considerably impact the environment (Journal of Law from 2010 No 213, position 1397 with amendments). The decree enumerates the type of projects belonging to the category of those capable of having a significant impact on the environment. They were described and divided into objects and processes [Harasymiuk, Fadrowski 2013]. Each of the undertakings mentioned in the decree is characterized by an appropriate size, capacity or length, enabling qualification to a given division.

The undertakings capable of exerting a potentially significant impact on the environment are, among others, production facilities, commercial and service facilities, or recreational parks and golf courses. The decree also enumerates the road and bridge objects of hard surface of the length exceeding $1 \mathrm{~km}$, not mentioned in the group of those always significantly impacting the environment.

\section{CONDITIONS OF ENVIRONMENTAL DECISION}

Investments, which are classified as always capable of exerting a significant impact on the environment require an assessment of the environmental impact. If an undertaking is classified as capable of exerting a potentially significant impact on the environment, the duty of making an impact assessment lies on the appropriate body for issuing a decision on environment-related conditions. The essence of the procedure of an impact assessment involves a prediction of the potential threats at the stage of investment planning. This procedure is to provide the information to the administrative body which makes a decision, if the interference of the investment on the environment has been optimally planned [Wilżak 2011]. The procedure of conducting an environmental impact assessment is connected with the decision on environment-related conditions. This decision is to determine the conditions of carrying out a given undertaking from the point of view of environmental protection. It is crucial that the assessment of environmental results of carrying out a given investment is accomplished at the earliest stage of the investment process [Nowak 2012].

In the case of the undertakings, for which a mandatory report (from group I) is required, determination of its scope occurs as an answer to the appropriate inquiry submitted by the investor. The parliamentary act foresees one exception in this case and places the onus on the mover to submit an inquiry on the scope of a report if a given investment may have a cross-border impact on the environment. The requirements pertaining to the report on environmental impact are to be found in article 52 section 1, 1b, 1c, 2, 3 and $4 \mathrm{a}$ of the Law of Environment Protection, Journal of Laws from 2001 No. 62, item 627. The requirements for each undertaking are all the same, conditioned by the nature of a given investment and in the scale of environmental impact associated with the project.

The requirements for a report made for an investment connected with the building of state roads exclude the obligation of reporting localization variants for the projects dealing with the building or rebuilding a road, for which the decision of determining the localization of these projects had been issued. It does not exclude the necessity of reporting the variants of a different nature than that of localization and especially of the technical variants.

In the case of the projects which do not belong to the category of being capable of exerting a significant impact on the environment, but capable of exerting a considerable impact on area covered by Natura 2000, the question of the obligation to obtain a decision on environment-related conditions lies not on the investor but on the appropriate decision making body as determined by article 46 section 4 of Law of Environment Protection, Journal of Laws from 2001, No. 62, item 627, or receiving a notification as pertains to section 4 of that article. If the decision making body decides that a given project may exert a significant impact on the area covered by Natura 2000, it should wait till concluding the matter in due time by obtaining a decision on environment-related conditions via the investor [Florkiewicz 2007].

\section{SUBMISSION OF AN APPLICATION AND WAITING TIME}

A proper decision making bodies for the environment-related conditions are:

1. Head of municipality, mayors, mayors of a city - with exceptions reserved for the RDEP,

2. Regional Director of Environment Protection (RDEP) - in the case of:

a) undertakings which are always capable of exerting a significant impact on the environment: 
roads, railway lines, overhead electrical lines, pipelines, chemicals or gas, as well as nuclear facilities and storage places for nuclear waste;

b) undertakings carried out in confined areas;

c) undertakings carried out in marine areas;

d) the change of a forest, which is not property of

the State Treasury to agricultural land;

In the case of the formal inaccuracies in the application for issuing a decision on environment-related conditions, the investor is summoned to sort them out in the means provided by article 64 of the Code of Administrative Procedure, within 7 days - with the information that leaving any inaccuracies will result in the application being unsettled.

For the undertakings from group I reports are mandatory, for projects from group II and III - the obligation of making a report may be determined. Determining the need for making this type of document and determining its scope are done after the submission of the motion for issuing a decision on environment-related conditions. Yet, even if the proper body stated the lack of obligation in making a report for a given project, it is not exempted from the obligation of issuing a decision on environment-related conditions.

Opinions on the necessity of a report and its scope are issued either in written form or in the form of a resolution, on which a plaint is not vested (in the manner of art. 123 CAP The appropriate body has 14 days to issue an opinion on the scope of a report, while the resolution on the necessity of making a report and on its scope should be issued within 30 days. Both deadlines are counted from the date of receiving a complete set of documents by the body, in accordance to the parliamentary act. A resolution on the necessity of making a report and on its scope is issued in the manner stated in art. 123 CAP and, in accordance to the parliamentary act of the Law of Environment Protection of April 2001, a plaint on it is allowable. The issuing of a resolution is also compulsory in the case, when the body issu- ing a decision on environment-related conditions decides that in a given case the preparation of a report is not necessary.

\section{DESCRIPTION OF THE RESEARCH AND ANALYSIS OF THE RESULTS}

The regulations on issuing an environmental decision contain no obligatory deadlines on the part of the bodies issuing these decisions. Only the manner as determined by the CAP are applicable here [Harasymiuk, Kowalczyk 2016]. Yet, in practice, these guidelines are seldom applied and the entire procedure considerably prolongs the determined deadlines. The research done on the basis of the data of the regional director of environment protection in Olsztyn shows how long one must wait for the issuing of an environmental decision. In the analysed period, the regional director of environment protection issued 67 environmental decisions on building investments. Only in 19 cases, was the full assessment of environment impact required, and in 48 cases only the simplified procedures were applied. The proceeding was done by grouping investments in accordance to the different natures of the projects.

Roads constitute the first category of investments which were analysed. In the research, the periods of time of waiting for a decision on investments, requiring both a report and an information card were taken into account (Table1).

In the table, the average period of waiting for a decision on environment-related conditions in RDEP in Olsztyn was presented. It is clearly visible that in many cases the waiting periods exceed the deadlines set out in the administrative procedure. The record-holder of the time of waiting for issuing an environmental decision proved to be the enlargement of provincial road No. 519 between Małdyty and Morąg (variant W of the construction), because the time from the submission of the application for a decision by the proxy of the investor to the time of its issue

Table 1. An average time of waiting for issuing a decision for road investments on the basis of the information of RDEP in Olsztyn

\begin{tabular}{|c|c|c|c|c|}
\hline $\begin{array}{l}\text { Decisions on environment-related conditions issued } \\
\text { in the years of } 2012-2015\end{array}$ & 2012 & 2013 & 2014 & 2015 \\
\hline Investments requiring an information card of an undertaking - total & 124 & 69 & 72 & 104 \\
\hline - building and rebuilding commercial and service facilities & 95 & 49 & 53 & 32 \\
\hline - building and extension of water-supply and sewage systems & 274 & 68 & 62 & 78 \\
\hline
\end{tabular}

Source: On the basis of the data from RDEP in Olsztyn. 
by the regional director of environment protection took 1422 days. It is a result of, among other things, the difficulty in forming a description of the environmental impact and completion of the environmental documentation.

The analyses also showed that in the majority of cases, the time required for the road investments is considerably longer than for other kinds of investment.

The Figures 1 and 2 clearly show that the road investments required significantly more time for carrying out the necessary procedures than other investments included by the obligation of making a report and an information card for an undertaking.

The data presented in Table 2 show the average time of waiting for a decision for electrical in- frastructure investments. Contrary to road investments, the time required for examining the application and for issuing a decision is, in most analysed cases, shorter than for investments in general.

Figure 3 shows that the difference between these values is considerable. Graph 3 also presents the decreasing tendency of the values of the average waiting time for a decision of environment-related conditions. Figure 4 shows a slightly increasing tendency of the analysed quantity, but the differences are not big.

Table 3 shows the information concerning the waiting time for a decision on environmentrelated conditions in the case when an information card of a project is required. In this group, the commercial and service facilities as well as water-supply and sewage installations consti-

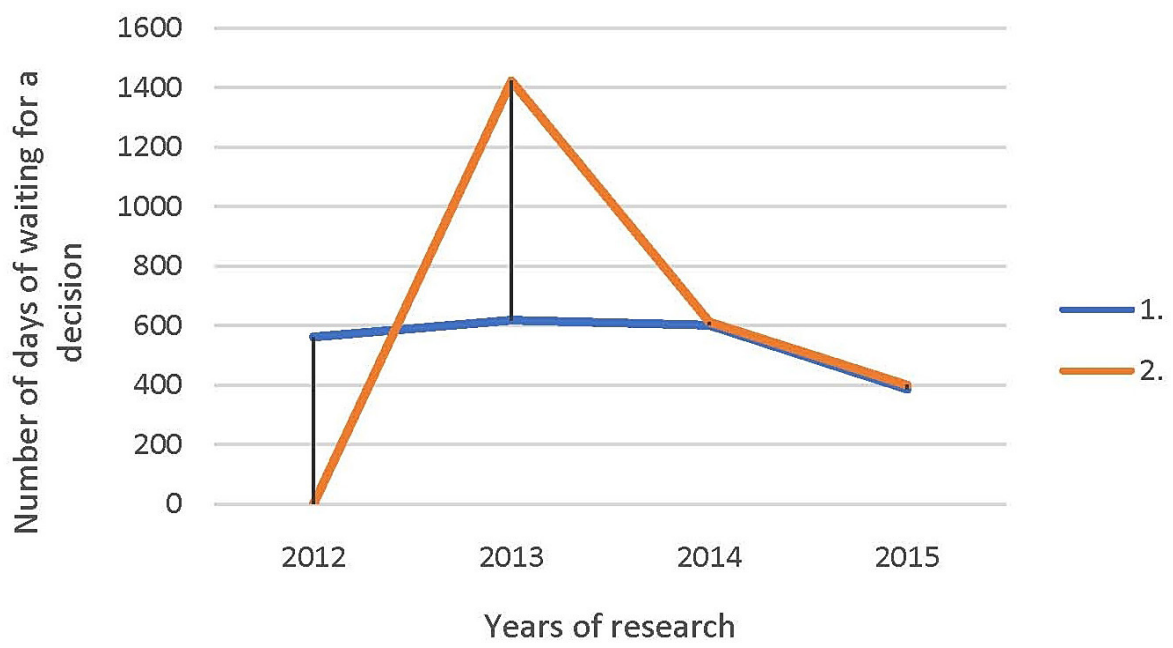

Figure 1. Waiting time for an environmental decision for the road investments requiring a report

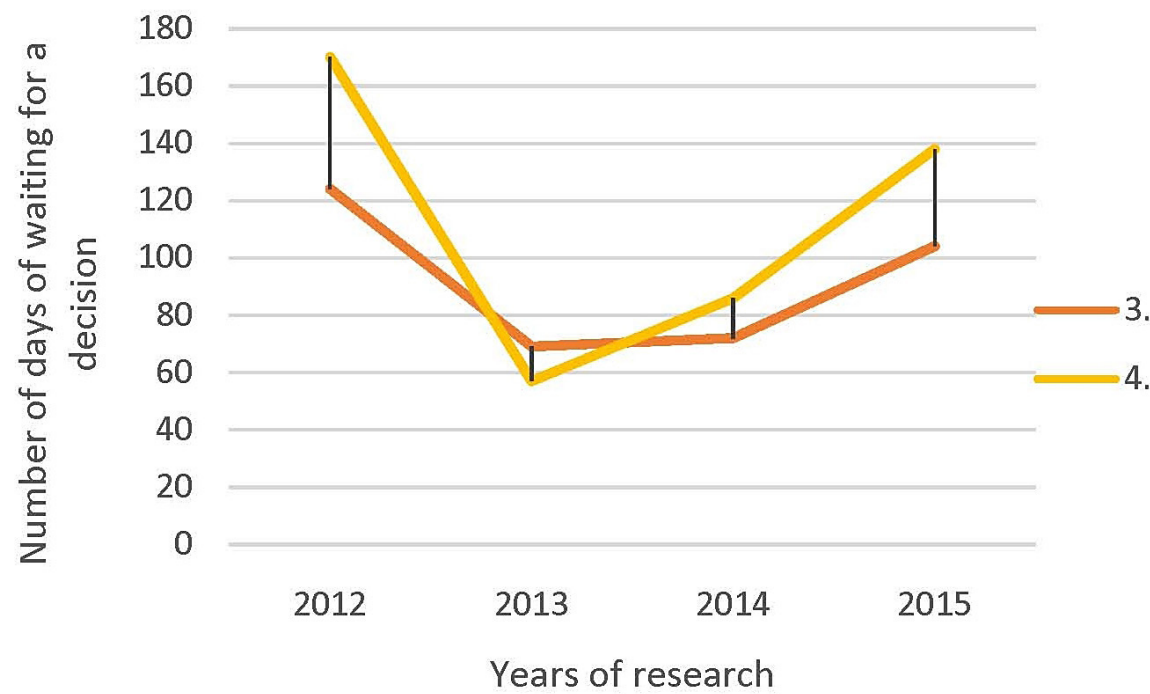

Figure 2. Waiting time for an environmental decision for the road investments requiring an information card of an undertaking 
Table 2. Average waiting time for issuing a decision for electric infrastructure investments on the basis of the information from RDEP in Olsztyn

\begin{tabular}{|l|c|c|c|}
\hline $\begin{array}{c}\text { Decisions on environment-related conditions issued } \\
\text { in the years of } 2012-2015\end{array}$ & 2012 & 2013 & 2014 \\
\hline Investments requiring an information card of an undertaking - total & 124 & 69 & 72 \\
\hline - building and rebuilding commercial and service facilities & 95 & 49 & 53 \\
\hline - building and extension of water-supply and sewage systems & 274 & 68 & 62 \\
\hline
\end{tabular}

Source: On the basis of the data from RDEP in Olsztyn.

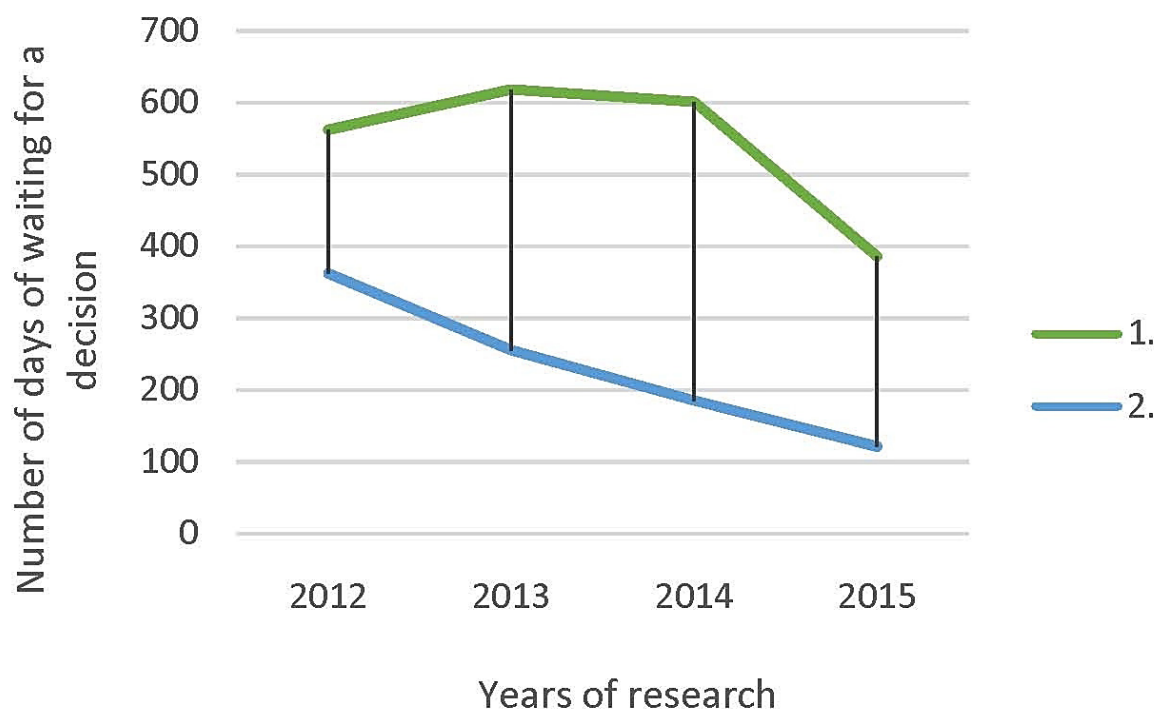

Figure 3. Waiting time for a decision for electric infrastructure investments requiring a report

Table 3. Mean time of waiting for issuing a decision for investments of different character on the basis of the information from RDEP in Olsztyn

\begin{tabular}{|c|c|c|c|c|}
\hline $\begin{array}{l}\text { Decisions on environment-related conditions issued } \\
\text { in the years of } 2012-2015\end{array}$ & 2012 & 2013 & 2014 & 2015 \\
\hline Investments requiring an information card of an undertaking - total & 124 & 69 & 72 & 104 \\
\hline - building and rebuilding commercial and service facilities & 95 & 49 & 53 & 32 \\
\hline - building and extension of water-supply and sewage systems & 274 & 68 & 62 & 78 \\
\hline
\end{tabular}

Source: On the basis of data from RDEP in Olsztyn.

tute a considerable number. In most cases, the researched values are lower than the average for other undertakings in general. The exception includes the information pertaining to the investments of building and the extension of the water-supply and sewage infrastructure in 2012. The shortest average time of waiting for issuing an environmental decision in the analysed period occurred in the case of investments on building and rebuilding sewage systems. In most cases, the thoroughly prepared documentation, the involvement of the investor in the process of completing and delivery to the applicable body which conducted the proceedings and to the cooperating body and the perception of these investments as advantageous by society were decisive. Investments of this kind are, as a rule, long awaited and enjoyed support by both local authorities and local communities and, therefore, they do not meet significant procedural difficulties. Figure 5 proves these observations.

\section{CONCLUSION}

The principal aim of a decision pertaining to the environment-related conditions is to determine the conditions of carrying out a building undertaking with the consideration of environmental protection. The preparation of documentation 


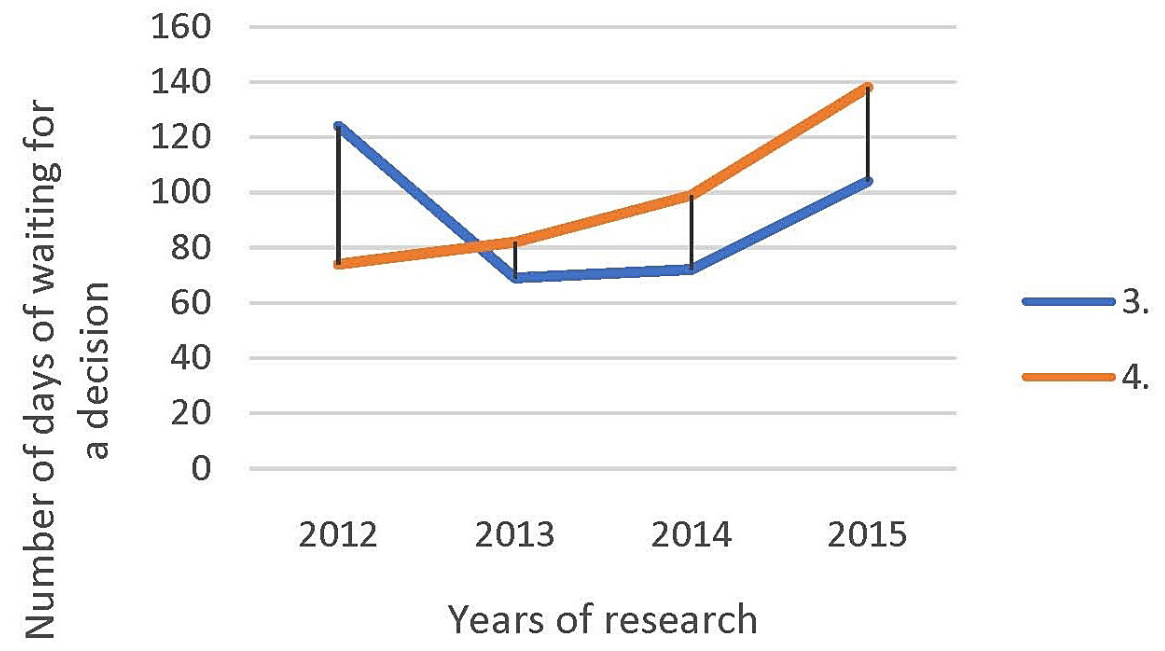

Figure 4. Waiting time for a decision for an electric infrastructure investment requiring an information card of an undertaking

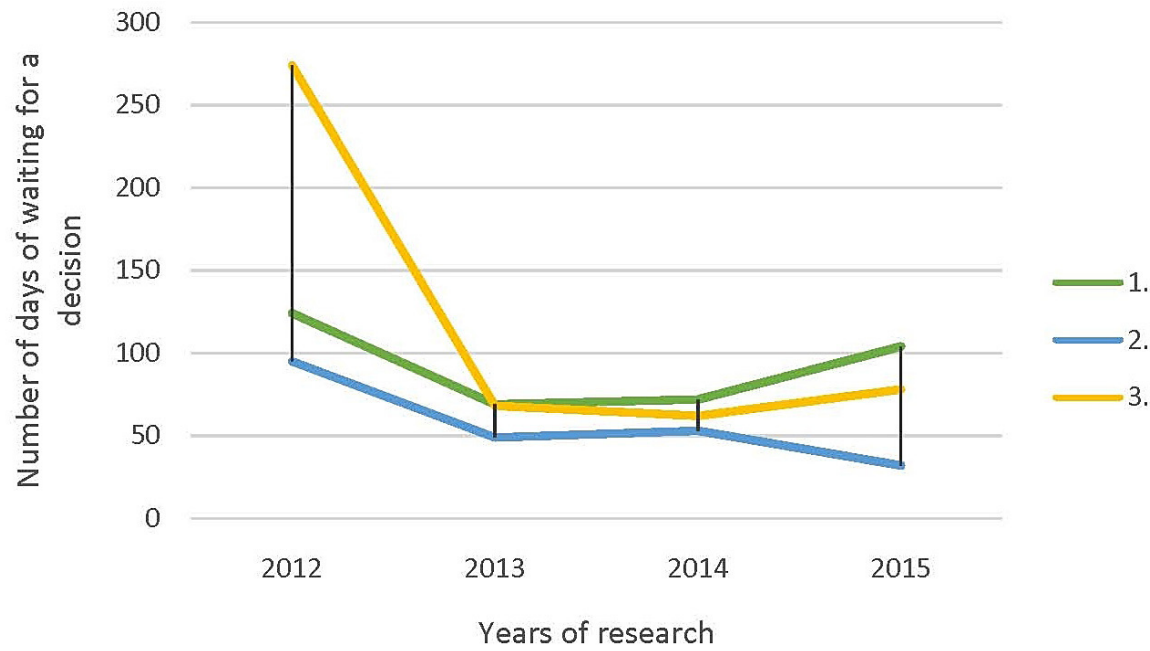

Figure 5. Waiting time for a decision for commercial and service investments as well as water-supply and sewage investments requiring an information card of an undertaking

pertaining to the fulfillment of regulatory requirements is both arduous and labour-intensive. The research showed that the time connected with an environmental decision may prolong the process of preparing an investment by as much as 2-3 years. As a result of the source materials analysis it was concluded that the prolongation of the time of obtaining a decision is influenced mostly by the necessity of completing the documentation by an investor and of carrying out supplementary expert environmental examination. It was proved that the appropriate involvement in the procedure and focusing on the fast and faultless preparation of documents may considerably shorten this waiting period.

\section{REFERENCES}

1. Ciechanowicz-McLean J. 2001. The international law of environmental protection. Law Publishing House - LexisNexis, Warszawa (in Polish).

2. Ejdys J., Kobylińska U. \& Lulewicz-Sas A. 2012. Integrated systems of quality management, the environment and work safety. Białystok Politechnics Publishing House, Białystok (in Polish).

3. Florkiewicz E. 2007. The conduct of environmental impact studies for planned undertakings. http:// www.ekoportal.gov.pl/ (in Polish).

4. Harasymiuk J., Fadrowski S. 2013. Selected problems in issuing environmental decisions based on experiences of the province of Warmia and Mazury in the years of 2009-2011. Scientific Review - En- 
gineering and Evironmental Science, 61, 348-360 (in Polish).

5. Harasymiuk J., Kowalczyk Z. 2016. The expectation time for a decision on the environmental conditions on the example of the example of the province of Warmia and Mazury. Building Materiale, 6, 149-151 (DOI: 10.15199/33.2016.06.65) (in Polish).

6. Komornicki T., Wiśniewski R., Baranowski J., Błażejczyk K., Degórski M., Goliszek S. \& Zawiska I. 2015. The influence of the selection of road corridors on the natural environment and socio-economic development of adjacent areas. Stanisław Leszczycki Institute of Geography and Spacial Management of the Polish Academy of Science, Vol. 249 (in Polish).
7. Nowak M. J. 2012. Decision on environment-related conditions, as an instrument of the management of sustainable growth on the local scale in Poland. Regional Studies - Studia Regionalne i Lokalne, (4)/50, 111-125 (in Polish).

8. Szafranko E. 2014. Environment-related conditions of the development of the road network in Poland, as a part of the EU transport system. Logistics, 6, 12986-12997 (in Polish).

9. Wierzbowski B., Rakoczy B. 2007. The legal basis of the law of environmental protection. Law Publishing House - LexisNexis, Warszawa (in Polish).

10. Wilżak T. 2011. Undertakings which may have a considerable impact on the environment - a guide to the decree of the Council of Ministers. General Directory of Environment Protection (in Polish). 